\title{
Humans as Genetic Information Carriers in the Pandemic Conditions (Criminal, Criminal Legal, and Civil Legal Aspects)
}

\author{
Pavlovska Nataliia \\ PhD of Juridical Sciences, Associate Professor, Professor of Department \\ of Civil Law and Process of the National Academy of Internal Affairs, Kiev, \\ Ukraine \\ ORCID ID 0000-0003-3311-0364 wwwpav@gmail.com
}

\section{Kulyk Maryna}

PhD of Juridical Sciences, Associate Professor of Forensic Support and Forensic Expertise of the National Academy of Internal Affairs, Kiev, Ukraine ORCID ID 0000-0003-1373-6749 coolss777@ukr.net

\section{Tereshchenko Yuliia}

PhD of Juridical Sciences, Professor of Criminal Law Disciplines and Operative and Investigative Activities of the Precarpathian Department of the National

Academy of Internal Affairs, Kyiv, Ukraine ORCID ID 0000-0002-5353-0887 vladysikter@ukr.net

\section{Strilets Halyna}

PhD of Judicial Sciences, Associate Professor of the Departament of Law of Prydunai Branch of Private Jointstock Company «Higher Educational Institution of Interregional Academy of Personnel Management», Izmail, Ukraine

ORCID ID 0000-0002-1067-0820 galinastrelets2018@ gmail.com

\section{Filipova Natalia}

Asistant of the Departament of Law of Prydunai Branch of Private Jointstock

Company «Higher Educational Institution of Interregional Academy of

Personnel Management», Izmail, Ukraine

ORCID ID 0000-0001-7132-8343 filinatalja2310@gmail.com

\footnotetext{
Abstract

It has been for the most part difficult and almost impossible to establish the origin of biological material from a particular person, as traditional methods of examining biological traces only with little probability can
} 
establish the relative chances of origin of such traces from a particular person and not their equivalence or identity.

The development and implementation in the expert practice of new methods of research of human biological traces are aimed at increasing the level of identification capabilities. Major successes in this area have been achieved first of all due to molecular genetics. The importance of such research cannot be overestimated. Many of the notable advances we witness today in forensics and the biological sciences depend on our knowledge of the structure of deoxyribonucleic acid (DNA).

Key words: DNA research, physical evidence, biological traces of man, blood, hair, saliva, semen, urine, sweat, genome, molecular genetic research.

\section{Introduction The substance of DNA profiling.}

The object of the DNA profiling can be DNA obtained from blood, secretions (sperm, saliva, buccal and other epithelium, etc.), hairs (if they retain hair follicles with root sheath), as well as fragments of organs and tissues of a human body. Cut hair, urine and sweat are not suitable for examination by these methods as they lack cells with nuclear DNA.

It is known that the DNA molecule retains its inherent individual specificity in any nuclear cell of the organism (only monozygotic twins have identical DNAs) and does not change throughout human life. Therefore, it is possible to identify within a DNA profiling a certain number of features that make it possible, with a high probability of $99 \%$, to establish that human biological traces belong to a particular person, as well as the biological affinity of persons. Besides, DNA profiling makes it possible to identify the sex of persons whose items are being examined [12].

The latest achievements in the field of molecular genetics have been gradually introduced into the practice of the Department of Medical and Biological Expertise of the State Research Forensic Centre (SRFC) of the Ministry of Internal Affairs of Ukraine which made it possible to perform DNA profiling examinations at the world level. The European Association of Forensic Sciences has confirmed the high quality of DNA research there by issuing its international certificate [1].

\section{Factors influencing the suitability of DNA for a polymerase chain reaction.}

The examination of the Department's best practices made it possible to establish that difficulties in the DNA extraction from the items to be examined were mainly related to the following factors: putrefactive changes in blood samples (from corpses); improper extraction, storage and transportation of items; adding anticoagulants to liquid blood samples; various diseases related to the immune system [11]. 
It is imperative to keep in mind that collecting material for genetic analysis requires that blood samples for comparison be taken carefully, with sterile instruments, using masks and gloves.

\section{Grounds for a DNA forensic examination (research).}

Provisions of orders to appoint the examination of traces of biological origin should be drafted, taking into account the purposes of the investigation, the circumstances of the crime, and expert opportunities. This means that, in each criminal proceeding, there should be close contact between the investigator, who appoints a DNA examination, and a specialist (forensic technician), preferably with a degree in biology and forensics, and such contact should provide for the joint appropriate selection of physical evidence for examination, determination of expertise opportunities, with due account of the evidence available to investigators, and the agreement on requests to be put before the expert $[3,15]$.

The main objectives of such examination are:

1) establishing the belonging of items of biological origin (blood, sperm, saliva, hair, muscle and bone tissues) to a certain person,

2) establishing whether traces of biological origin may belong to a certain person,

3) whether the DNA profile of a certain person is present in mixed traces of biological origin (blood, sperm, saliva, epithelial cells, etc.).

If the identity of the remains needs to be established when a corpse [9] is dismembered and if victims should be identified whose close relatives are living, the main questions are

1) can certain individuals be the biological parents of the person whose corpse's remains are to be examined;

2) can certain people be the parents of a child in cases of disputed paternity, infanticide, child abduction or substitution;

3) can certain individuals be the biological parents of a particular child?

\section{Current opportunities for the DNA research of human biological traces in times of pandemics.}

Today, DNA profiling is a fundamentally new type of scientific knowledge that opens up reliable prospects for solving problems related to identification in criminal proceedings and the development of the evidence base and has a number of advantages over traditional serological methods of human biological traces research, which are as follows: 
the presence of DNA molecules in every nuclear cell of the human body;

the increased resistance of the DNA structure to physical and chemical environmental factors;

no impact from the carrier;

mixing of biological materials from two or more persons can be established;

micro traces can be examined; mixed traces can be differentiated (for example, sperm and epithelial cells of a victim if sex crimes are investigated);

conclusions on the belonging of traces to a certain person are highly reliable;

expert conclusions presented in court are reliable and illustrative [10];

public confidence in criminal proceedings is growing.

As DNA profiling is highly developed nowadays, it should be used to solve and investigate offences against persons.

For over 20 years, the Unit of Biological Research of the SRFC MIA of Ukraine has been using the DNA profiling to perform examinations in the proceedings on serious crimes (murder, rape, etc.) and to establish blood kinship (disputed paternity). The latest achievements in the field of molecular genetics have been gradually introduced into the practice of the SRFC MIA of Ukraine and made it possible to perform examinations by DNA profiling at the world level. ABI Avant genetic analyzers (3100, 3130, and 3500) manufactured by APPLIED BIOSYSTEM (USA) and modern sets of reagents that allow identifying a person with a high degree of probability (1:10 billion) are used to perform research in compliance with the world standards. Now the Unit of Molecular Genetic Research of the SRFC MIA of Ukraine performs the most sophisticated and complex examinations, as well as the examination of mitochondrial DNA.

At present, it is important to perform complex research, which should include both investigative methods and comparative identification mentioned above, as precisely the combination of these provides the greatest effectiveness of crime detection. The lessons learned demonstrate that comprehensive examination of physical evidence seized during the inspection of the scene is the most effective method [14].

The most important requirement is the priority application of such methods, where physical evidence retains as much as possible traces for further research. Also, the quantitative characteristics of an item and the quality of its condition are crucial for the 
examination.

Besides, modern reagents allow isolating DNA from various organs and tissues (bones) of the human body (for example, when dismembered, skeletal or charred corpses are found), which currently allows establishing genetic traits of bones in $95 \%$ of cases.

Currently, the expert service has tested a technique that makes it possible, while detecting 2-5 or more papillary lines with no individual signs, to examine the presence of epithelial cells and establish their DNA profile. This examination method allows establishing the DNA profile of fingerprints after treating trace objects with certain fingerprint powders (nozzle soot, zinc oxide and the solution of ruthenium (IV) oxide) [5].

In the course of DNA research, no specific features pertinent only to a given individual are identified. Each feature has only group membership properties, but together they make it possible to individualize the object. However, this does not preclude that several people may exist at the same time with features identical to that of the object under examination. The allele is the main identifier.

To assess identification significance of such features, probabilistic and statistical processing of research results should be performed, based on the laws of probability theory. The distribution of alleles in the population is probabilistic, meaning that the frequency of occurrence of a particular allele in the examined population can be assessed with an established degree of reliability. The number of individuals in a given population with a particular allele determines the frequency (probability) of that allele, which is established experimentally. Occurrence frequency data make it possible to calculate the probability of identifiers.

If the DNA profile of the object coincides with the genotypes of the suspect and the victim and none of the hypotheses can be excluded, the issue has no solution.

One way to use microsatellite sequence polymorphism analysis is to solve the disputed parentage of children. Such analysis is ordered in civil law proceedings as a rule. However, the expert practice has cases when the origin of a child from a particular individual is required to be established in connection with criminal offences. The most typical situations are the following:

establishing paternity if rape resulted in the victim's pregnancy (with subsequent childbirth or premature termination of pregnancy); 
establishment of maternity in examinations in cases of infanticide;

determining the child's parentage from specific persons in case of child substitution or abduction.

Disputed paternity is the case category which most frequently requires the examination of a disputed origin of children.

\section{Obtaining biological samples in times of pandemic.}

Nowadays, the study of human genetic material is the core of forensic DNA profiling, which has increased public confidence in the criminal justice and judiciary and the reliability of evidence before the court [3].

However, in performing such examinations, it is important to research not only objects of biological origin, but also relevant samples to fully identify traces found during crime scene inspections, and obtain appropriate biological samples to establish paternity or family ties. The legislator poses here no limits on the experts, having provided, on the contrary, in Article 245 of the Criminal Procedure Code of Ukraine, the right to obtain samples for examination $[2]$.

In particular, if samples for the examination should be taken, it is done by the party to the criminal proceedings which applied for the examination or at whose request the investigating judge has appointed such examination. If a court has ordered the examination, then the court itself or a professional involved on its behalf should take samples for it. However, samples of blood and other secretions of the human body should be taken only in health institution settings and in due compliance with the sanitary standards excluding any harmful consequences for a person whose samples are being taken. While taking samples, the investigator should be governed by relevant instructions and methodological guidance.

Biological samples should be taken for examination under the procedure established in Article 241 of the Criminal Procedure Code (CPC) of Ukraine for the examination of an individual. Biological samples should be taken upon the order of a public prosecutor and, if necessary, with the participation of a forensic medical examiner or a physician, or individuals capable of performing such procedure [2].

Obtaining biological samples accompanied by denudation of the individual as well as the relevant procedures should be performed by individuals of the same sex, except for a situation when they are performed by a physician and upon the consent of the individual 
whose samples are being taken. Investigators and prosecutors have no right to be present when biological samples are taken from an individual of other sex if it involves the denudation of the individual.

The individual should be presented with the prosecutorial order before taking biological samples. The individual is afterwards requested to give his or her biological samples voluntarily. When biological samples are taken from an individual, it shall be not permitted to humiliate honour and dignity or endanger his or her health. The record should be drawn up when biological samples are being taken from an individual.

If an individual refuses to give his or her biological samples voluntarily, then a party to criminal proceedings may file a motion to an investigative judge or a court to request to obtain biological samples. Such motions are considered under the procedure provided in Articles 160-166 of the CPC [2].

Having considered the motion, the investigative judge or court allows the investigator or prosecutor to take biological samples forcibly or obligates them to take them forcibly if the defence has filed the motion. The individual whose biological samplings are forcibly taken should be presented with the copy of the record of such procedure.

Given that human biological samples are inextricably linked to the integrity of the organism (blood, skin, epithelial tissue, other tissues, etc.), their forced extraction without the consent of a person, involves the moral or physical impact on such person. Furthermore, Article 43 of the Fundamentals of Health Care Legislation of Ukraine clearly provides that voluntary consent of the person is a necessary condition for any preliminary medical intervention [4].

Thus, the provision of the CPC where the legislator provided for the forced obtaining of biological samples, is quite a novelty. In particular, Article 245 (3) of the CPC of Ukraine provides that, should the person refuse to voluntarily provide biological samples, an investigating judge or a court, upon a motion of a party to criminal proceedings, considered in accordance with the procedure established in Articles 160-166 of the Code, shall have the right to give permission to the investigator or public prosecutor to take biological samples in a compulsory manner (or to oblige them to do so if the motion was filed by the defence). However, as of today, the procedure for such action is left without legal regulation, and this, 
in general, provides grounds for the violation of constitutional human rights and freedoms related to personal integrity $[7,8]$.

In particular, Article 29 of the Constitution of Ukraine provides that every person shall have the right to personal inviolability. Therefore, the mentioned amendment to the Code is too "sensitive" and requires clear legal regulation, as such forced action if non-compliant with the procedure established in the CPC, including mandatory involvement of disinterested persons (official witnesses), etc., gives rise to significant violations of the provisions of criminal procedural law, and accordingly may call into question the impartiality of the results of such expert examination.

In light of such concerns, the issue of forcible taking biological samples for expert examinations requires further consideration and visibility provided by both scientists and practitioners.

Conclusions Human biological traces always played a great role in the detection and investigation of serious crimes. As the number of crimes against persons keeps growing, the application of such traces as carriers of forensically relevant information requires professional approaches [6].

The DNA profiling is only one of the identification stages, as a statistical analysis of data received is necessary to obtain final results, which is crucial if genotypes of an offender and a victim coincide, as sometimes in such cases human lives are at stake. For probabilistic and statistical evaluation of the results of the relevance of established genetic traits for the purposes of identification, the frequencies of their occurrence need to be established.

As of today, DNA profiling (DNA fingerprinting) is one of the most prospective areas of forensic development; its results provide quite reliable evidence of a certain person's involvement in a crime. Due to its unique opportunities, DNA profiling (fingerprinting) became a powerful tool in investigating crimes [13].

Therefore, the effectiveness of a successful solution of each criminal case in the fight against crime at both the local and national levels depends on the effectiveness of law enforcement, which can be increased only with constant cooperation and coordination between operational and investigative units and the expert service of the Ministry of Internal Affairs of Ukraine. International cooperation in exchanging DNA profiles between European countries would contribute to improving international police collaboration. 


\section{References}

1. The Law of Ukraine "On National Police" of 2 July 2015, Bulletin of the Verkhovna Rada of Ukraine, 2015, Nos. 40-41, p. 379.

2. The Criminal Procedure Code of Ukraine of 13 April 2012, Bulletin of the Verkhovna Rada of Ukraine, 2013, Nos. 9-10, 11-12, 13, p. 88.

3. The Law of Ukraine "On forensic examination" of 25 February 1994, Bulletin of the Verkhovna Rada of Ukraine, 1994, No. 28, p. 232.

4. The Law of Ukraine "Fundamentals of Health Care Legislation of Ukraine" of 19 November 1992, No. 2801-XII, retrieved from http://zakon4.rada.gov.ua/laws/show/2801-12.

5. The Regulation on the Expert Service of the Ministry of Internal Affairs of Ukraine, approved by the Order of the Ministry of Internal Affairs of Ukraine of 3 November 2015 No. 1343, retrieved from http://zakon3.rada.gov.ua/laws/show/z1390-15.

6. The Instruction on the procedure for involving the police pre-trial investigation officers and the Expert Service of the Ministry of Internal Affairs of Ukraine in the scene examination, approved by the Order of the Ministry of Internal Affairs of Ukraine of 3 November No. 1339, retrieved from http://zakon3.rada.gov.ua/laws/show/z1392-15.

7. The European Convention on Human Rights (the Convention for the Protection of Human Rights and Fundamental Freedoms) of 4 November 1950, Human Rights and Professional Standards for Legal Professionals in the Documents of International Organisations, Amsterdam, Kyiv, 1996, pp. 12-17.

8. Kotliarenko, L. T. Biological human rights: fundamentals, reality or an experiment, Forensics: current status and prospectives for the development, round table materials (23 April 2015). Kyiv, NNIFEKP NAVS, 2015, pp. 193-196.

9. Kotliarenko, L. T. Certain aspects of a corpse examination: the role of forensic experts and specialists, Issues relevant to forensic support to criminal proceedings, round table materials (10 April 2014), Kyiv, 2014, pp. 130-132.

10. Kotliarenko, L. T. Legal regulation of obtaining biological samples for expert examination, L. T. Kotliarenko, Issues relevant to technical and forensic support of criminal proceedings, round table materials (21 November 2013), Kyiv, 2013, pp. 171-173.

11. Utility model patent "The Box for Items of Biological Origin", No. 116198. URL: http://elar.naiau.kiev.ua/jspui/handle/123456789/2316

12. Forensic research of human biological traces. URL: http://elar.naiau.kiev.ua/jspui/handle/123456789/2993

13. Forensic research of biological items. URL: http://elar.naiau.kiev.ua/jspui/handle/123456789/1705

14. The participation of a forensic expert in some investigative actions. URL: http://elar.naiau.kiev.ua/jspui/handle/123456789/16325

15. Forensics: lecture notes, Kobylianskyi, O. L., Kofanov, A. V., Kyiv, 2019. 